\title{
Effect of ABT-888 on the apoptosis, motility and invasiveness of BRAFi-resistant melanoma cells
}

\author{
FEDERICA FRATANGELO $^{1}$, ROSA CAMERLINGO ${ }^{1}$, MARIA VINCENZA CARRIERO ${ }^{1}$, GIUSEPPE PIROZZI ${ }^{1}$, \\ GIUSEPPE PALMIERI $^{2}$, GIUSY GENTILCORE ${ }^{1,3}$, CONCETTA RAGONE $^{1,4}$, MICHELE MINOPOLI $^{1}$, \\ PAOLO ANTONIO ASCIERTO ${ }^{1}$ and MARIA LETIZIA MOTTI ${ }^{1-5}$ \\ ${ }^{1}$ Istituto Nazionale Tumori -IRCCS- 'Fondazione G. Pascale', 80131 Naples; ${ }^{2}$ Unit of Cancer Genetics, \\ Institute of Biomolecular Chemistry, National Research Council, 07100 Sassari, Italy; ${ }^{3}$ Division of Translational Medicine, \\ Sidra Medical and Research Centre, 26999 Doha, Qatar; ${ }^{4}$ Department of Experimental Medicine, \\ University of Campania 'Luigi Vanvitelli', 81100 Caserta; ${ }^{5}$ Department of Sport Science and Wellness, \\ University 'Parthenope', 80133 Naples, Italy
}

Received April 2, 2018; Accepted June 12, 2018

DOI: 10.3892/ijo.2018.4457

\begin{abstract}
Melanoma is a molecularly heterogeneous disease with many genetic mutations and altered signaling pathways. Activating mutations in the BRAF oncogene are observed in approximately $50 \%$ of cutaneous melanomas and the use of BRAF inhibitor (BRAFi) compounds has been reported to improve the outcome of patients with BRAF-mutated metastatic melanoma. However, the majority of these patients develop resistance within 6-8 months following the initiation of BRAFi treatment. In this study, we examined the possible use of the poly(ADP-ribose) polymerase 1 (PARP1) inhibitor, ABT-888 (veliparib), as a novel molecule that may be successfully employed in the treatment of BRAFi-resistant melanoma cells. Sensitive and resistant to BRAFi dabrafenib A375 cells were exposed to increasing concentrations of ABT-888. Cell viability and apoptosis were assessed by MTT assay and Annexin V-FITC analysis, respectively. The cell migratory and invasive ability was investigated using the xCELLigence technology and Boyden chamber assays, respectively. ABT-888 was found to reduce cell viability and exhibited pro-apoptotic activity in melanoma cell lines, independently from the BRAF/NRAS mutation status, in a dose-dependent manner, with the maximal effect being reached in the 25-50 $\mu \mathrm{M}$ concentration range. Moreover, ABT- 888 promoted apoptosis in both the sensitive and resistant A375 cells, suggesting that ABT-888 may be useful in the treatment of BRAFi-resistant subsets of melanoma cells. Finally, in accordance with the involvement
\end{abstract}

Correspondence to: Dr Paolo Antonio Ascierto, IRCCS Istituto Nazionale Tumori 'Fondazione G. Pascale', Via Mariano Semmola 53, 80131 Naples, Italy

E-mail: paolo.ascierto@gmail.com

Key words: ABT-888, poly(Adenosine diphosphate-ribose) polymerase 1 , melanoma, BRAF inhibitor resistance of PARP1 in actin cytoskeletal machinery, we found that the cytoskeletal organization, motility and invasive capability of both the A375 and A375R cells decreased upon exposure to $5 \mu \mathrm{M}$ ABT-888 for $24 \mathrm{~h}$. On the whole, the findings of this study highlight the pivotal role of PARP1 in the migration and invasion of melanoma cells, suggesting that ABT-888 may indeed be effective, not only as a pro-apoptotic drug for use in the treatment of BRAFi-resistant melanoma cells, but also in suppressing their migratory and invasive activities.

\section{Introduction}

Malignant melanoma is an aggressive tumor of the skin with a poor prognosis for patients with advanced disease. Despite novel therapeutic treatments developed in recent years, patients with advanced melanoma continue to succumb to the disease. Over the past decade, many efforts have been made to enhance our understanding of the molecular biological mechanisms associated with the development of melanoma, and several of the key alterations affecting the regulation of cellular proliferation- and viability-related pathways have been identified $(1,2)$. Over $50 \%$ of melanoma cases harbor activating V600E mutations in BRAF $\left(\mathrm{BRAF}^{\mathrm{V} 600 \mathrm{E}}\right)$, which sustains the proliferation and survival of melanoma cells by activating the mitogen-activated protein kinase (MAPK) pathway (2-6). Thus, there is an ongoing effort to develop small molecules acting as inhibitors of the activated effectors into the MAPK pathway. Among these, vemurafenib and dabrafenib, two inhibitors of the mutated BRAF (mostly, BRAF ${ }^{\mathrm{V} 600 \mathrm{E}}$ mutation), have been documented to significantly improve the clinical outcome of patients with metastatic melanoma $(7,8)$. Although both vemurafenib and dabrafenib positively affect progression-free and overall survival, their prolonged use as single agents is limited due to the consistent development of drug resistance (9). Indeed, the majority of patients who initially respond to treatment with BRAF inhibitor (BRAFi), relapse within 6-8 months, suggesting that chronic treatment with BRAFi may strongly induce the activation of molecular 
mechanisms overcoming the anti-proliferative effects of such drugs (10). The resistance to therapy with BRAFi is mostly associated with the re-activation of the MAPK pathway through different molecular mechanisms, including NRAS upregulation (in some cases, through the functional loss of the RAS-antagonist, NF1 protein), the acquisition of activating mutations in the downstream MAP2K1 gene, BRAF amplification and/or the expression of inhibition-escaping splicing isoforms of BRAF ${ }^{\mathrm{V} 600 \mathrm{E}}$ (11-17). Specific inhibitors of MEK1 and MEK2 kinases, including selumetinib, trametinib, cobimetinib and binimetinib, have been introduced into clinical practice for the treatment of BRAF- and NRAS-mutated metastatic melanomas (18-20). In fact, the combination of BRAF and MEK inhibitors is recognized as the standard of care for the targeted therapy of BRAF-mutated metastatic melanomas $(21,22)$. However, several molecular alterations involved in the resistance to BRAFi may play a similar role in the acquisition of resistance to MEK inhibitors $(23,24)$. Therefore, there is still an unmet need for additional therapeutic strategies for the treatment of BRAFi-resistant melanomas.

The poly(ADP-ribose) polymerase (PARP) family includes 17 different enzymes that regulate different cellular functions, such as the regulation of the cell cycle, gene transcription and the regulation of the repair mechanisms of DNA damage (25). Since they seem to be essential for the maintenance of genomic stability, PARP proteins are indeed attractive therapeutic targets. PARP inhibitors are being widely investigated as a class of useful drugs for use in the treatment of tumors with underlying defects in DNA repair, or when combined with DNA-damaging agents (26).

The most abundant isoform of the PARP enzyme family, PARP1, plays a key role in the mechanisms of the repair of single-strand DNA breaks through the base excision repair pathway $(27,28)$. In BRCA1- or BRCA2-deficient cells which are defective of homologous recombination, the inhibition of PARP1 leads to an increase in DNA double-strand breaks. This results in chromosomal instability, cell cycle arrest and subsequent apoptosis (26). Accumulating evidence demonstrates that PARP1 interacts with various oncogenic proteins and regulates several transcription factors, thereby modulating a broad variety of cellular functions (29). In an orthotopic murine model of melanoma, PARP1 silencing has been shown to hamper angiogenesis, reduce intra-tumor vascularization and tumor growth, and to enhance the sensitivity to temozolomide (30). Among the PARP inhibitors, the PARP1/2 inhibitor, ABT-888 (veliparib), is an orally bioavailable small molecule with pre-clinical efficacy without signs of toxicity in tumor models, including melanoma (31), and is currently being investigated in a number of ongoing clinical trials for the treatment of solid tumors $(32,33)$ (NCT01690598, NCT02289690, NCT02723864, NCT03123211). Emerging evidence indicates that the efficacy of ABT-888 in delaying the PARP-mediated repair of DNA damage is potentiated by the concomitant administration of chemo- and/or radiotherapeutic agents which concur to accumulate DNA strand breaks $(31,34)$. In particular, Palma et al demonstrated that ABT-888 enhanced the efficacy of temozolomide in a variety of pre-clinical tumor models, including B-cell lymphoma, pancreatic, breast, ovarian, non-small cell lung carcinoma and small-cell lung carcinoma models (34).
In this study, using a number of human melanoma cell lines harboring different mutations in the BRAF or NRAS genes, we examined the effects of ABT-888 on the growth and invasiveness of melanoma cells which are either sensitive or resistant to the BRAFi, dabrafenib.

\section{Materials and methods}

Cell lines and treatments. The human melanoma cell line, A375, was purchased from ATCC (Manassas, VA, USA); the SK-MEL-2, SK-MEL-5, 397-MEL, LOX-IMVI and M14 cell lines were kindly provided by Dr F.M. Marincola (Sidra Medical and Research Center, Doha, Qatar). The human melanoma M-368 cells were provided by Dr A. Ribas (UCLA Medical Center, Santa Monica, CA, USA). The LCP and COPA-159 melanoma cells were established in the laboratories of the Istituto Nazionale Tumori 'Fondazione G. Pascale'IRCCS and passaged for $<6$ months. The LCP cells are derived from a primary lesion of a patient with malignant melanoma, whereas the COPA-159 cells are derived from an axillary lymph node metastasis removed from a patient with a melanoma progressive disease $(35,36)$. The SK-MEL-2, SK-MEL-5, A375, COPA-159, LOX-IMVI, LCP, 397-MEL and M-368 melanoma cell lines were grown in RPMI-1640 medium, and the M14 cell line in DMEM medium, both supplemented with $10 \%$ fetal bovine serum (FBS), $100 \mathrm{IU} / \mathrm{ml}$ penicillin and $50 \mu \mathrm{g} / \mathrm{ml}$ streptomycin, and maintained in $25 \mathrm{~cm}^{2}$ tissue culture flasks at $37^{\circ} \mathrm{C}$ in humidified air with $5 \% \mathrm{CO}_{2}$. ABT-888 supplied by AbbVie Inc. (Chicago, IL, USA), was dissolved in DMSO (Sigma-Aldrich, St. Louis, MO, USA) at a stock concentration of $50 \mathrm{mM}$, and stored at $-20^{\circ} \mathrm{C}$. The cells were treated with diluent, 5, 10, 25 or $50 \mu \mathrm{M}$ ABT-888 for 24 or $72 \mathrm{~h}$ in complete growth medium prior to being subjected to functional assays. The A375R sub-line with acquired resistance to dabrafenib (purchased from GlaxoSmithKline, Brentfort, UK) was generated by growing the parental A375 cells in the presence of increasing concentrations of dabrafenib (from $1 \mathrm{nM}$ up to $25 \mathrm{nM}$ ) over a period of 4 months. BRAFi $\mathrm{IC}_{50}$ values of 138 and $331 \mathrm{nM}$ were determined for the parental A375 and A375R cells, using the logistic function (or sigmoidal) to fit dose-response curves, using GraphPad statistical software. Following selection, the A375R cells were maintained in growth medium supplemented with $25 \mathrm{nM}$ dabrafenib for at least 8 weeks before performing the experiments.

Analysis of cell viability by 3-(4,5-dimethylthiazol-2-yl)2,5-diphenyltetrazolium bromide (MTT) assay. The viability of the melanoma cell lines was assessed by using the MTT colorimetric assay. Viable cells with active metabolism convert MTT into the corresponding, purple-colored formazan, while dead cells lose their ability to convert MTT into formazan. The cells $\left(3 \times 10^{3}\right.$ cells/well) suspended in complete growth medium, were seeded in 96-well plates. After $24 \mathrm{~h}$, the medium was replaced with $100 \mu \mathrm{l}$ fresh medium containing the vehicle ( $0.001 \%$ DMSO), the indicated concentrations of ABT-888 or dabrafenib. Following $72 \mathrm{~h}$ of incubation at $37^{\circ} \mathrm{C}$ in humidified air with $5 \% \mathrm{CO}_{2}$, the suspended cells were removed and the adherent cells were stained with $0.5 \mathrm{mg} / \mathrm{ml}$ sterile MTT dye solution (Invitrogen, Carlsbad, CA, USA) for $4 \mathrm{~h}$ at $37^{\circ} \mathrm{C}$. The resulting formazan was eluted with $100 \mu \mathrm{DMSO}$ and 
measured at a wavelength of $540 \mathrm{~nm}$ using a microplate reader (Bio-Rad, Hercules, CA, USA). For each cell line, data were calculated as a percentage of the absorbance of untreated cells, considered $100 \%$.

Annexin V-FITC assay. The apoptotic response of the melanoma cells to ABT-888 was evaluated using the Annexin V-FITC apoptosis detection kit (eBioscience, Santa Clara, CA, USA), according to the manufacturer's instructions. Briefly, the cells (1x10 $10^{5}$ cells/sample) were incubated with $5 \mu$ l Annexin V-FITC diluted in $200 \mu \mathrm{l}$ binding buffer for $10 \mathrm{~min}$ at room temperature in the dark, washed with binding buffer, incubated with $10 \mu \mathrm{l}$ propidium iodide (PI, $20 \mu \mathrm{g} / \mathrm{ml}$ ) in $190 \mu \mathrm{l}$ binding buffer and immediately analyzed using a BD FACSAria II flow cytometer (BD Biosciences, Franklin Lakes, NJ, USA).

Cell cycle analysis by flow cytometry. The cells were harvested and washed once with phosphate-buffered saline (PBS), fixed in pre-cold $70 \%$ ethanol and incubated with $50 \mu \mathrm{g} / \mathrm{ml}$ PI (Sigma-Aldrich), $1 \mathrm{mg} / \mathrm{ml}$ RNase solution, for $60 \mathrm{~min}$ at $4^{\circ} \mathrm{C}$ in the dark. The stained nuclei were analyzed with a FACS Vantage cell sorter, and the data were analyzed using a Mod-Fit 2.0 cell cycle analysis program (both from BD Biosciences). Flow cytometric analysis was performed using a BD FACSAria II flow cytometer (BD Biosciences), and the data were analyzed using ModFit software (Verity Software House, Topsham, ME, USA).

Western blot analysis. The cells were lysed in RIPA buffer (10 mM Tris pH 7.5, $140 \mathrm{mM} \mathrm{NaCl,0.1 \%} \mathrm{SDS,} 1 \%$ Triton X-100, $0.5 \% \mathrm{NP}-40$ ) containing protease inhibitor mixture (Sigma-Aldrich) and the protein content was measured by a colorimetric assay (Bio-Rad). Proteins (30 $\mu \mathrm{g} / \mathrm{sample})$ were separated on $10 \%$ SDS-PAGE and transferred onto Immobilon PVDF membranes (Millipore, Darmstadt, Germany). The membranes were blocked with 5\% non-fat dry milk and probed with anti-human PARP1 monoclonal antibody (mAb; 1:1,000; 551024; BD Biosciences, Franklin Lakes, NJ, USA) recognizing both full length enzyme $(160 \mathrm{kDa})$ and the $85-\mathrm{kDa}$ cleaved PARP fragment and then with peroxidase AffiniPure goat anti-mouse IgG (H+L) (code: 115-035-003; 1:4,000; Jackson ImmunoResearch Europe Ltd., Cambridgeshire, UK). Chemiluminescence was developed by ECL and detected using ImageQuant LAS 500 software (both from GE Healthcare Life Sciences, Little Chalfont, UK).

Fluorescence microscopy. To visualize the cytoskeleton, the cells ( $2 \times 10^{4} /$ sample) were seeded on glass coverslips and cultured for $24 \mathrm{~h}$ in growth medium. The slides were then washed with PBS, fixed with $2.5 \%$ formaldehyde, permeabilized with $0.1 \%$ Triton $\mathrm{X}-100$ for $10 \mathrm{~min}$ at $4^{\circ} \mathrm{C}$, and incubated with $0.1 \mu \mathrm{g} / \mathrm{ml}$ rhodamine-conjugated phalloidin (Sigma-Aldrich) for $40 \mathrm{~min}$. Nuclear staining was performed with 4-6-diamidino2-phenylindole (DAPI) dye. Finally, coverslips were mounted using 20\% (w/v) Mowiol, and visualized with an Axiovert $200 \mathrm{M}$ fluorescence inverted microscope connected to a video camera (Carl Zeiss, Oberkochen, Germany).

Migration of cells monitored in real-time. Cell migration was monitored in real-time using the xCELLigence Real-Time Cell
Table I. Human melanoma cell lines harboring different mutations in BRAF or NRAS genes.

\begin{tabular}{ll}
\hline Melanoma cell lines & \multicolumn{1}{c}{ Mutation } \\
\hline SK-MEL-2 & NRAS $^{\text {Q61R }}$ \\
SK-MEL-5 & BRAF $^{\text {600E }}$ \\
M14 & BRAF $^{\text {600E }}$ \\
COPA-159 & BRAF $^{\text {600E }}$ \\
LOX-IMVI & BRAF $^{\text {6000E }}$ \\
LCP & BRAF $^{\text {V600R }}$ \\
397-MEL & BRAF $^{\text {6000 }}$ \\
M368 & BRAF wild-type \\
& NRAS wild-type
\end{tabular}

Analysis (RTCA) technology (Acea Bioscience, San Diego, CA, USA) as previously described (37). For these experiments, we used CIM-16-well plates which are provided with interdigitated gold microelectrodes on bottom side of a filter membrane interposed between a lower and an upper compartment. The lower chambers were filled with serum-free medium (CTRL) or growth medium (10\% FBS). Viable cells assessed by exclusion trypan blue $\left(2 \times 10^{4}\right.$ cells/well $)$ were seeded on filters in serum-free medium. Microelectrodes detect impedance changes which are proportional to the number of migrating cells and are expressed as cell index. Migration was monitored in real-time for $15 \mathrm{~h}$. Slopes represent the alteration rate of the cell index generated in a 1-15 h time frame. Each experiment was performed at least twice in quadruplicate.

Cell invasion assays. Cell invasion assays were performed in Boyden chambers, as previously described (38). Briefly, $4 \times 10^{4}$ cells/chamber were allowed to invade in Matrigel for $18 \mathrm{~h}$ at $37^{\circ} \mathrm{C}, 5 \% \mathrm{CO}_{2}$ using $8 \mu \mathrm{m}$ pore size Nuclepore Track-Etched Membranes (Whatman, Maidstone, UK) coated with $50 \mu \mathrm{g}$ Matrigel (BD Biosciences) and 10\% FBS in DMEM as a source of chemoattractants. At the end of the assay, cells on the lower filter surface were fixed with ethanol, stained with haematoxylin and counted in 10 random fields/filter at x200 magnification. The extent of cell invasion was expressed as a percentage of the basal cell invasion (CTRL), considered $100 \%$.

Statistical analyses. Data are presented as the means \pm SD and analyzed by one-way analysis of variance and a post hoc Dunnett's t-test for multiple comparisons. The software used was the SPSS statistical software version 23.0 (SPSS Inc., Chicago, IL, USA). Values of $\mathrm{P}<0.05$ and $\mathrm{P}<0.01$ were considered to indicate statistically significant and highly statistically significant differences, respectively.

\section{Results}

Effect of ABT-888 on melanoma cell viability. First, we examined whether ABT- 888 affects the viability of human melanoma cell lines harboring different mutations in the BRAF or NRAS genes. To this end, dabrafenib-sensitive melanoma cell lines listed in Table I were exposed to increasing concentrations of 


\section{ABT-888}
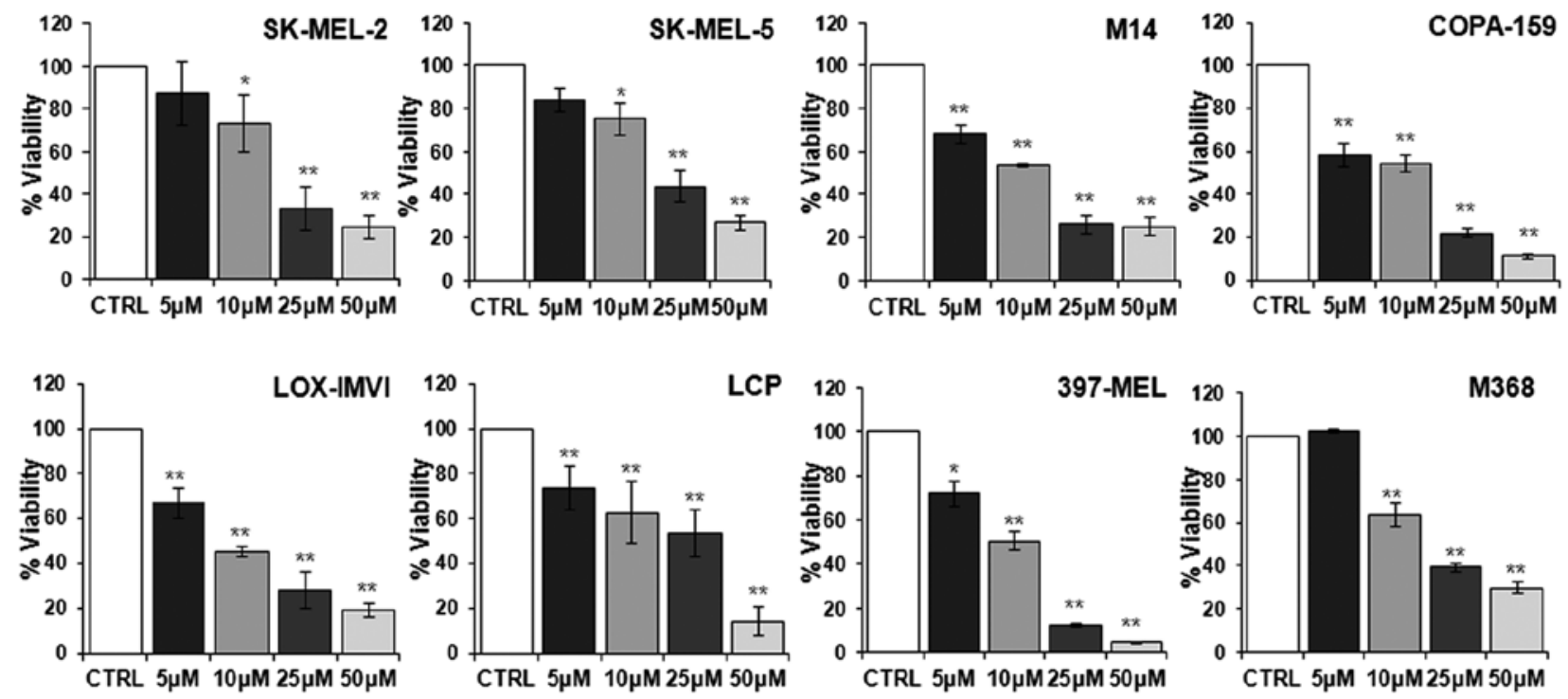

Figure 1. Dose-dependent inhibitory effect of ABT-888 on melanoma cell proliferation. Human melanoma cell lines were exposed to diluents (control; CTRL) or increasing concentrations of ABT- 888 for $72 \mathrm{~h}$ and their viability was assessed by MTT assay. Absorbance was detected at $540 \mathrm{~nm}$ with a microplate reader and data were expressed as a percentage of the CTRL. Data are the means \pm SD of 3 experiments performed in triplicate. Statistical significance was calculated against the CTRL $\left({ }^{*} \mathrm{P}<0.05 ;{ }^{* *} \mathrm{P}<0.01\right)$.

ABT- 888 for $72 \mathrm{~h}$ and their viability was assayed by measuring the mitochondrial activity of living cells by MTT assay. Data were expressed as a percentage of the absorbance detected in untreated cells (CTRL). As shown in Fig. 1, a slight decrease in the number of viable cells was observed from the concentration of $5 \mu \mathrm{M}$ ABT-888 in the majority of the cell lines, whereas an appreciable and statistically significant decrease in cell viability was observed in all the melanoma cell lines exposed to $10 \mu \mathrm{M}$ ABT-888. Following exposure of the cells to $25 \mu \mathrm{M}$ ABT- 888 , the number of total viable cells markedly decreased, apart from the LCP cells, which lost only $46 \%$ of their viability compared to the control. In any case, exposure of the cells to $50 \mu \mathrm{M}$ ABT-888 led to a significant loss of cell proliferation, ranging from $95-70 \%$ of the cell population for each cell line compared to the control (Fig. 1). These findings indicated that, although to a varying extent, ABT- 888 caused a dose-dependent decrease in the viability of melanoma cells, independently from their mutation status in the BRAF and/or NRAS genes, with the maximal decrease being observed in the $25-50 \mu \mathrm{M}$ concentration range.

Effect of ABT-888 on the apoptosis of melanoma cells. It has been reported that prolonged exposure to ABT- 888 induces the activation of the apoptotic program in the majority of cancer cell lines $(26,31)$. Thus, in this study, we investigated the apoptotic response of the melanoma cells to increasing concentrations of ABT-888. The cells were exposed to increasing concentrations of ABT-888 for $72 \mathrm{~h}$ and apoptotic cells were identified by FACS analysis, counting Annexin V-positive cells in the right upper (late apoptotic cells) and right lower (early apoptotic cells) quadrants of each panel. We observed that some of the untreated cells underwent overgrowth in the absence of any treatment (necrotic cells in the left upper quadrants). The majority of the melanoma cells underwent apoptosis following exposure to 25 or $50 \mu \mathrm{M} \mathrm{ABT}-888$ for $72 \mathrm{~h}$ (Figs. 2 and 3, and Table II), whereas only a weak pro-apoptotic effect was elicited by 5 or $10 \mu \mathrm{M}$ ABT-888 (Table II). These findings indicated that, although to a varying extent, ABT-888 induces the apoptosis of melanoma cells in a dose-dependent manner and independently from their mutation status in the BRAF and/or NRAS genes, with the maximal effect being reached in the 25-50 $\mu \mathrm{M}$ concentration range.

Effect of ABT-888 on the viability and apoptosis of A375 and A375R melanoma cells. The chronic treatment of melanoma with BRAFi is usually associated with the development of drug resistance (10). Thus, in this study, we investigated the possibility that ABT-888 exerts pro-apoptotic effects on melanoma cells which are resistant to BRAFi. Since approximately 50\% of melanomas harbor a BRAF mutation and in $90 \%$ of these cases, there is a substitution of a glutamic acid with a valine residue at position 600 (V600E) $(3,39)$, we employed A375 cells harboring the V600E mutation to generate dabrafenib-resistant A375 cells (A375R). The A375R cells were obtained by growing the parental A375 cells in the presence of increasing concentrations of dabrafenib (from 1-25 nM) for 4 months. The resistant A375 cells were preliminary analyzed for their ability to escape the dabrafenib-induced decrease in viability and proliferation by MTT assay and FACS cell cycle analysis, respectively. As shown in Fig. 4A, exposure of the cells to $25 \mathrm{nM}$ dabrafenib for $24 \mathrm{~h}$ elicited a marked cytotoxic effect on the A375 cells, but not on the A375R cells. FACS cell cycle analysis revealed that $25 \mathrm{nM}$ dabrafenib induced G0/G1 cell cycle arrest of the A375 cells, but not the A375R cells. The A375R cells retained the ability to progress into the $\mathrm{S}$ and $\mathrm{G} 2 / \mathrm{M}$ phases, thus confirming their acquisition of resistance to BRAFi (Fig. 4B-C). We then examined the effects of ABT-888 on A375 and A375R cell viability. The cells were treated with increasing concentrations of ABT-888 for $72 \mathrm{~h}$ and then subjected to an MTT assay as described 
Table II. Dose-dependent apoptotic effect of ABT-88 on melanoma cell lines.

\begin{tabular}{lcccrc}
\hline & \multicolumn{3}{c}{ Apoptotic cells (Q2+Q4) } \\
\cline { 2 - 6 } & CTRL & $5 \mu \mathrm{M}$ & $10 \mu \mathrm{M}$ & $25 \mu \mathrm{M}$ & $50 \mu \mathrm{M}$ \\
\hline COPA-159 & $8.2+0.01$ & $19.4+0.08$ & $31.3+0.02^{\mathrm{a}}$ & $54.2+0.14^{\mathrm{a}}$ & $76.2+0.16^{\mathrm{b}}$ \\
LCP & $6.2+0.07$ & $39.6+0.11^{\mathrm{a}}$ & $58.1+0.16^{\mathrm{a}}$ & $78.9+0.11^{\mathrm{b}}$ & $92.6+0.08^{\mathrm{b}}$ \\
M638 & $6.7+0.02$ & $17.5+0.13$ & $10.9+0.05$ & $49.9+0.02^{\mathrm{a}}$ & $84.5+0.12^{\mathrm{b}}$ \\
397-MEL & $2.4+0.12$ & $23.1+0.04^{\mathrm{a}}$ & $24.2+0.07^{\mathrm{a}}$ & $58+0.04^{\mathrm{b}}$ & $81.5+0.07^{\mathrm{b}}$ \\
SK-MEL-5 & $9.9+0.08$ & $13.2+0.05$ & $10.2+0.04$ & $24.2+0.05^{\mathrm{a}}$ & $34.1+0.01^{\mathrm{a}}$ \\
SK-MEL-2 & $8.5+0.13$ & $13.9+0.11$ & $13.3+0.04$ & $30+0.13^{\mathrm{a}}$ & $30.7+0.03^{\mathrm{a}}$ \\
M14 & $3.2+0.12$ & $30.4+0.14^{\mathrm{a}}$ & $50.3+0.16^{\mathrm{a}}$ & $66.8+0.08^{\mathrm{b}}$ & $73.6+0.05^{\mathrm{b}}$ \\
LOX-IMVI & $7.7+0.01$ & $12.1+0.06^{\mathrm{a}}$ & $7.8+0.08$ & $33.3+0.12^{\mathrm{a}}$ & $49.9+0.12^{\mathrm{a}}$ \\
\hline
\end{tabular}

Flow cytometric assessment of late $(\mathrm{Q} 2)$ and early $(\mathrm{Q} 4)$ apoptosis of melanoma cells after $72 \mathrm{~h}$ treatment with ABT-888. Treated cells with increasing concentration of ABT- 888 were stained with Annexin V-FITC and propidium iodide. Data are the means \pm SD of 3 experiments performed in triplicate. Statistical significance calculated against the CTRL $\left({ }^{\mathrm{a}} \mathrm{P}<0.05\right.$ and $\left.{ }^{\mathrm{b}} \mathrm{P}<0.01\right)$.
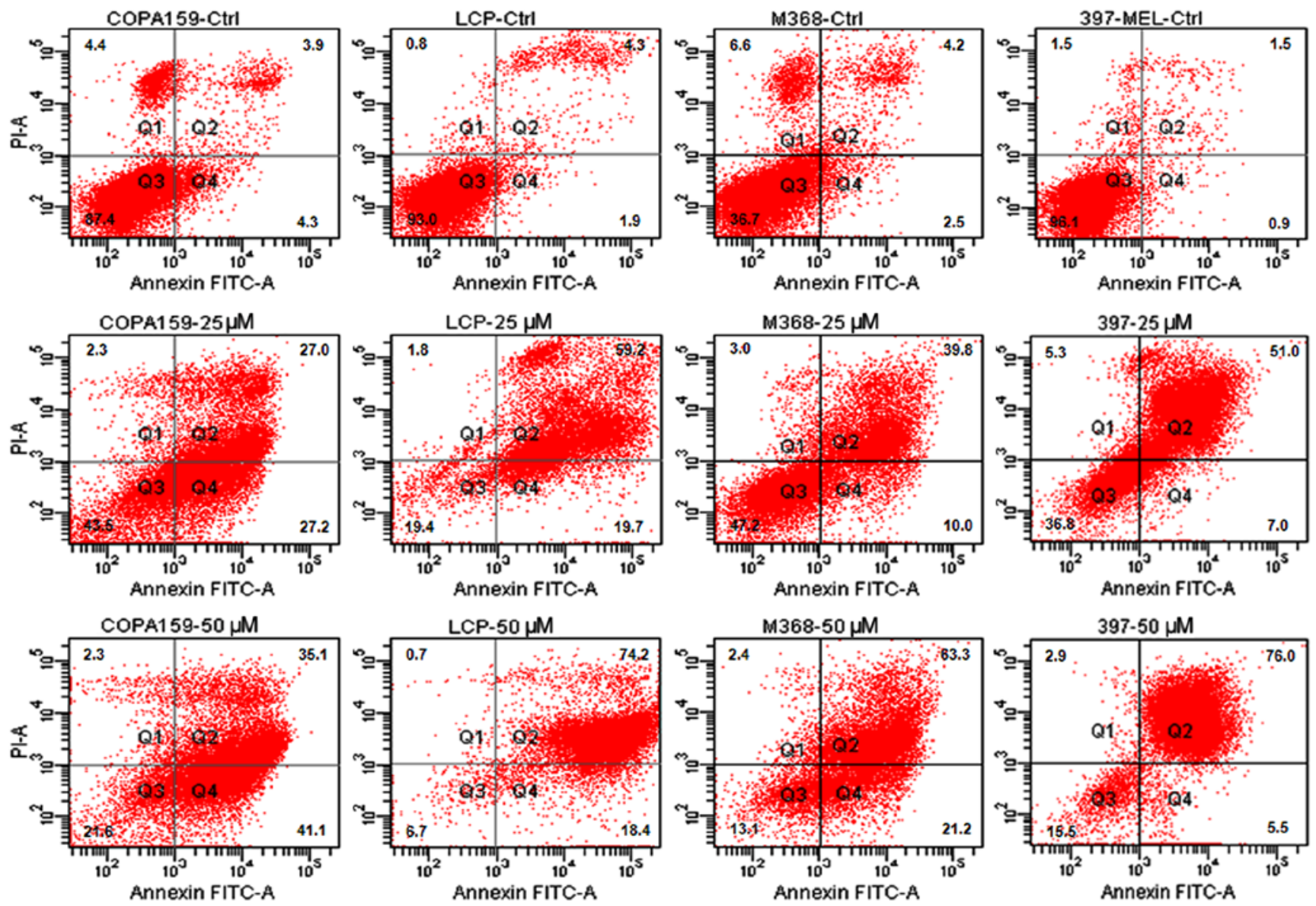

Figure 2. Dose-dependent pro-apoptotic effect of ABT-888 on melanoma cells. Human melanoma cell lines (COPA-159, LCP, M368, 397-MEL) were exposed to diluents (control; CTRL), or 25 or $50 \mu \mathrm{M}$ ABT- 888 for $72 \mathrm{~h}$. Cell apoptosis was analyzed by staining with Annexin V-FITC and PI followed by FACS analysis. The cells in quadrant $(\mathrm{Q}) 2$ and $\mathrm{Q} 4$ represent late and early apoptotic cells, respectively.

above. According to the data shown in Fig. 5A, ABT-888 induced a slight decrease in the number of viable cells from the concentrations of 5-10 $\mu \mathrm{M}$ in both the A375 and A375R cells. Upon exposure to $25 \mu \mathrm{M}$ ABT-888, the viability of the A375 and A375R cells decreased to 43 and 53\%, respectively, as compared to that of the untreated cells, while only a few viable cells were detected in both the sensitive and resistant cells treated with $50 \mu \mathrm{M}$ ABT-888 (Fig. 5A). FACS analysis of the Annexin V-positive A375 and A375R cells exposed to 25 or $50 \mu \mathrm{M}$ ABT-888 revealed a significant increase in the number of apoptotic cells in both cell populations, as compared to the untreated cells (Fig. 5B-C). At the 5 or $10 \mu \mathrm{M}$ 

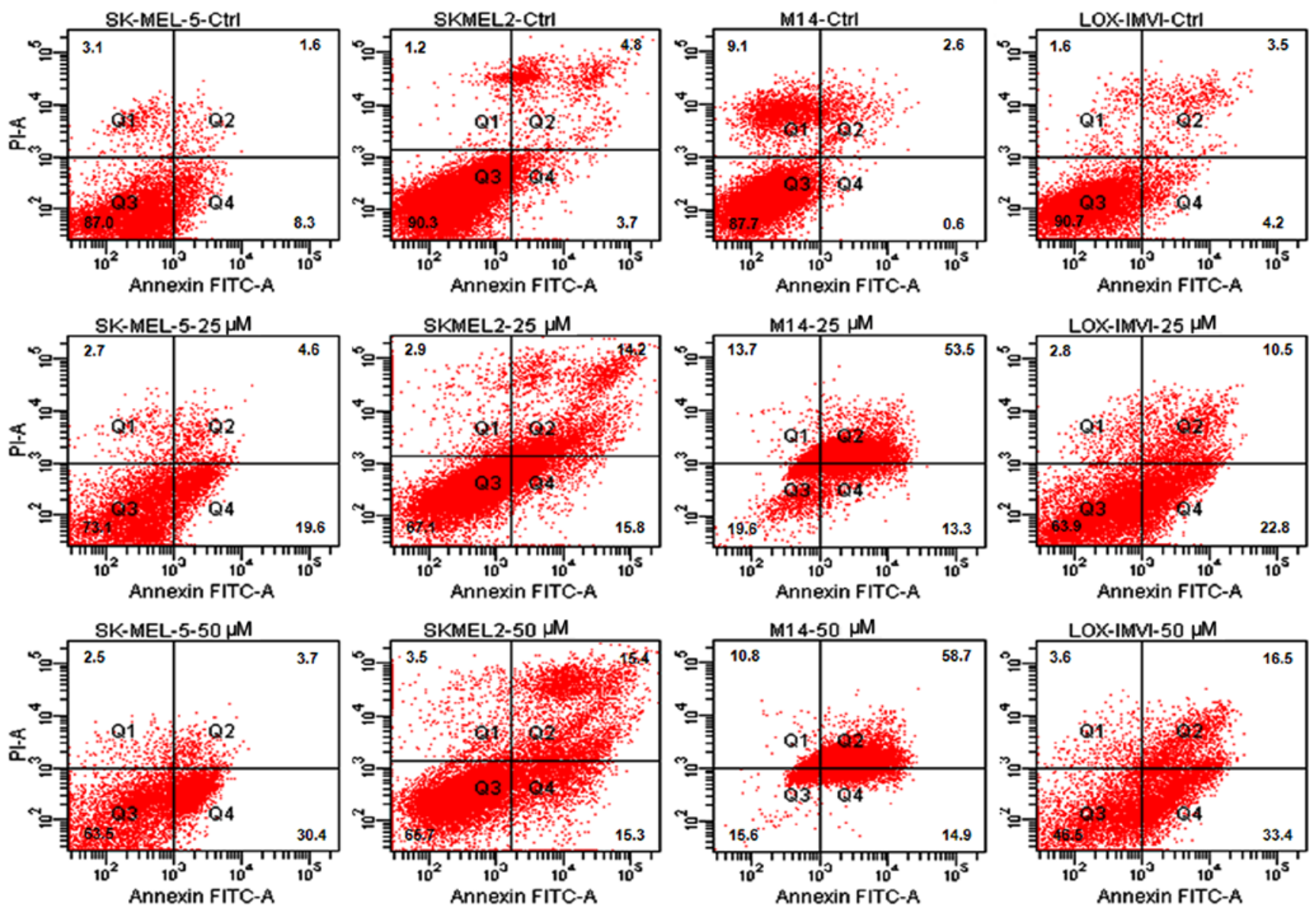

Figure 3. Dose-dependent pro-apoptotic effect of ABT-888 on melanoma cells. Human melanoma cell lines (SK-MEL-5, SK-MEL-2, M14, LOX-IMVI) were exposed to diluent (control; CTRL), or 25 or $50 \mu \mathrm{M}$ ABT- 888 for $72 \mathrm{~h}$. Cell apoptosis was analyzed by staining with Annexin V-FITC and PI followed by FACS analysis. The cells in quadrant (Q)2 and Q4 represent late and early apoptotic cells, respectively.

A

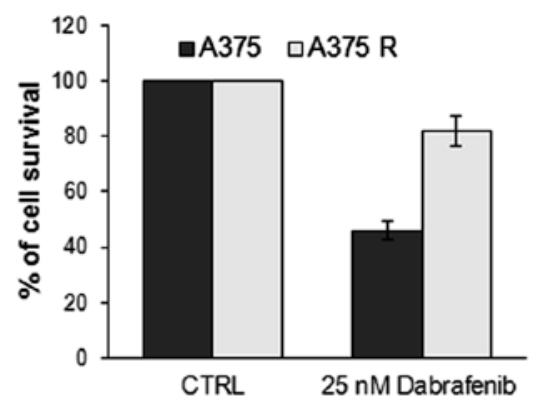

C

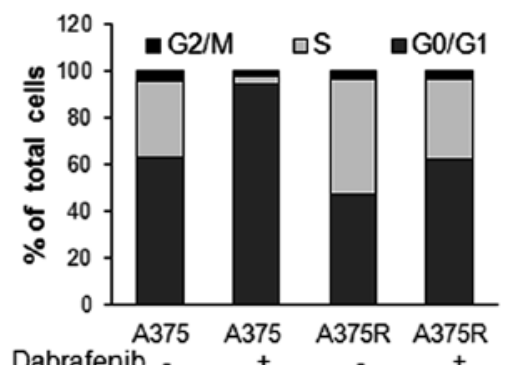

\section{B A375}
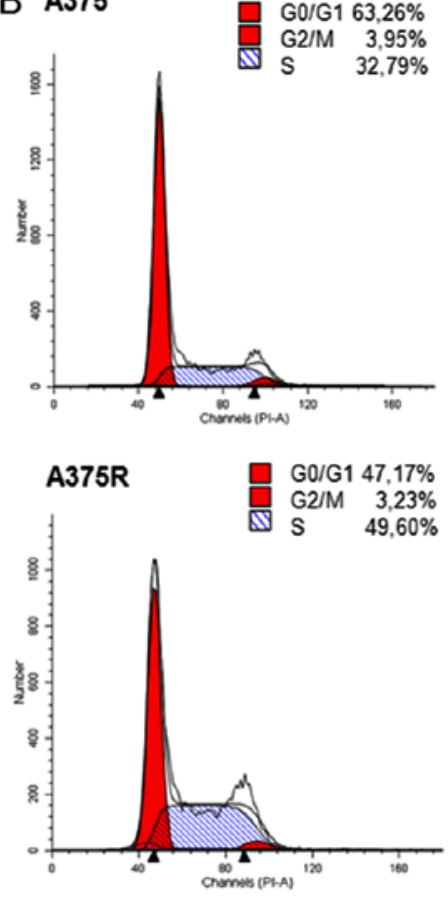
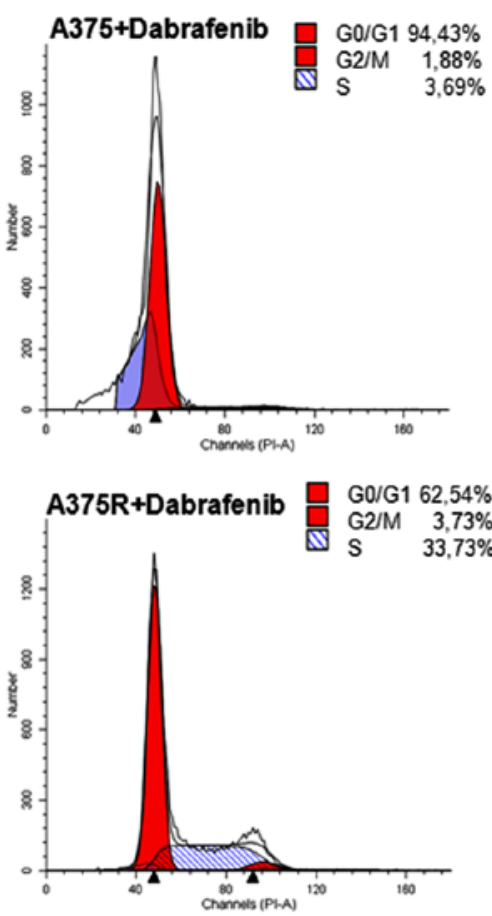

Figure 4. Comparison of the proliferation rate and apoptotic responses to dabrafenib of A375 and A375R melanoma cells. The A375 and A375R cells were exposed to $25 \mathrm{nM}$ dabrafenib for $24 \mathrm{~h}$. (A) Cell viability was assessed by MTT assay. Data are the means \pm SD of 3 experiments performed in triplicate. (B) The distribution of cells in the different cycle phases was analyzed by flow cytometry. (C) Histograms represent the percentages of different cycle phases. 
A

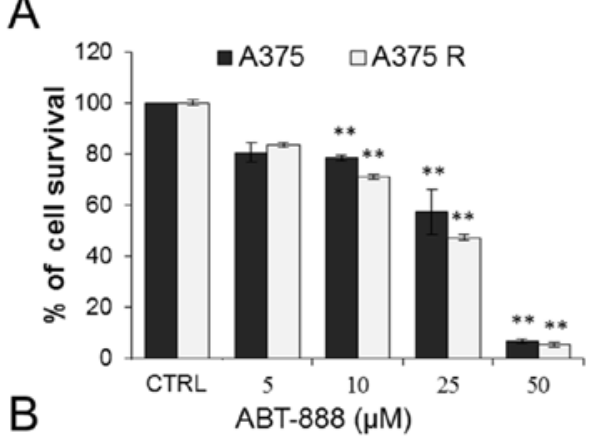

C

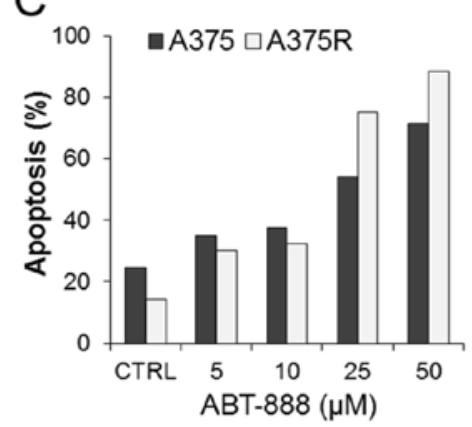

D A375
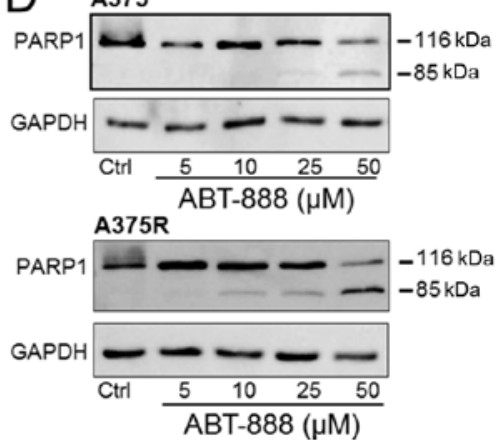
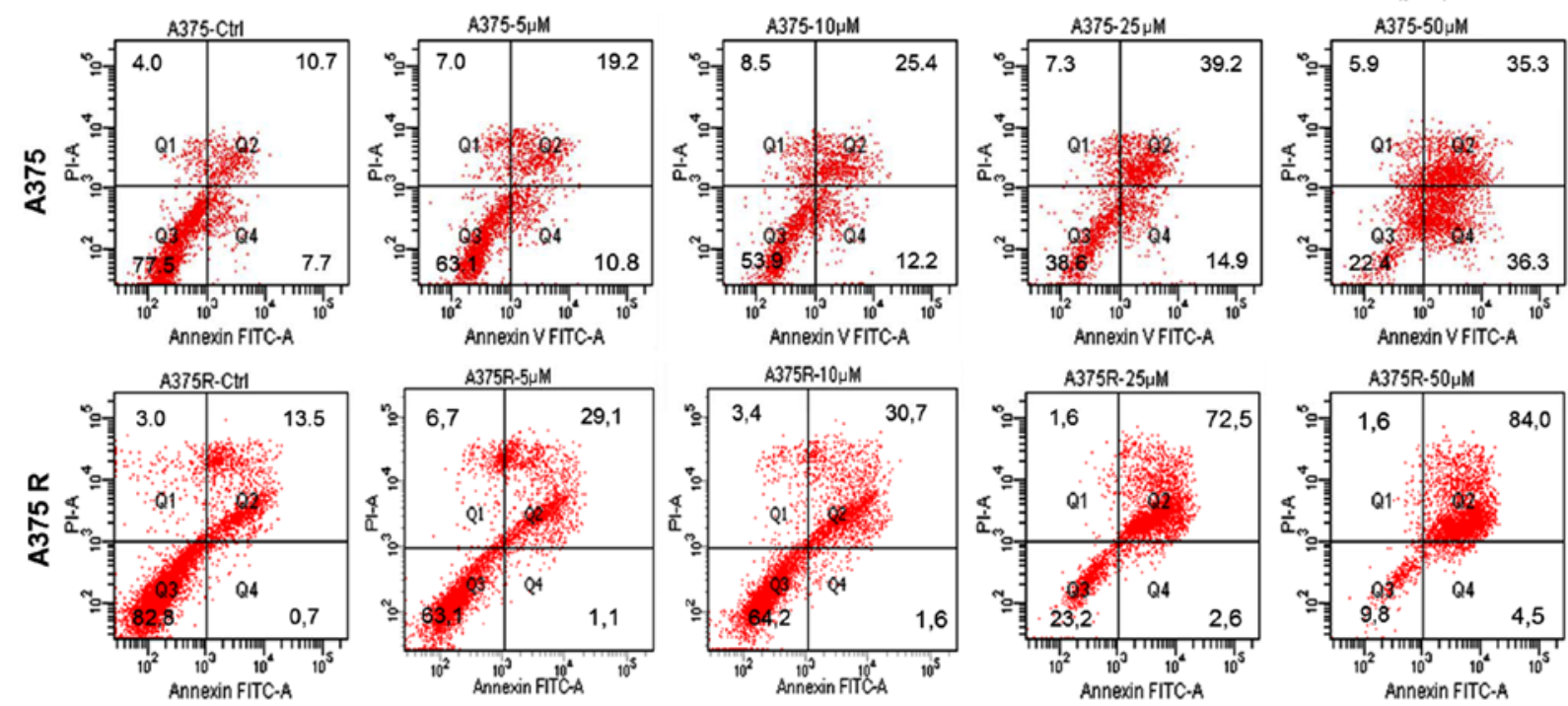

Figure 5. Dose-dependent inhibitory effect of ABT-888 on the proliferation rate of sensitive and resistant to BRAF inhibitor (BRAFi) A375 melanoma cells. A375 and A375R cells were exposed to diluents (control; CTRL) or increasing concentrations of ABT-888 for 72 h. (A) Cell viability was assessed by MTT assay. Data are expressed as a percentage of viable cells assessed in the absence of ABT- 888 . Data are the means \pm SD of an experiment performed in triplicate. Statistical significance calculated against the CTRL ( $\left.{ }^{* *} \mathrm{P}<0.01\right)$. (B) Cell apoptosis was analyzed by staining with Annexin V-FITC and PI followed by flow cytometric analysis. The cells in quadrant $(\mathrm{Q}) 2$ and Q4 represent late and early apoptotic cells, respectively. (C) Histograms represent the percentage of apoptotic cells. (D) Whole cell lysates (30 $\mu \mathrm{g} /$ sample) from A375 and A375R were resolved on a 10\% SDS-PAGE followed by western blot analysis with anti-PARP1 monoclonal antibody or anti-GAPDH polyclonal antibody as a loading control.

concentrations, ABT-888 exerted a slight pro-apoptotic effect on both A375 and A375R cells. Upon the exposure of the cells to $25 \mu \mathrm{M}$ ABT-888, the number of apoptotic A375 and A375R cells markedly increased, reaching 54,1 and $75,1 \%$ of the cell population, respectively. A further enhancement of the apoptotic effect was exerted on both the sensitive and resistant A375 cells exposed to $50 \mu \mathrm{M}$ ABT-888 (Fig. 5B-C).

PARP-1 inactivation is accompanied by the production of several specific proteolytic cleavage fragments with different molecular weights, which are considered markers of apoptosis. To confirm that ABT-888-dependent apoptosis occurs due to PARP-1 inhibition, the occurrence of a $85-\mathrm{kDa}$ cleaved PARP1 fragment was investigated in lysates from the A375 and A375R cells exposed to ABT- 888 by western blot analysis. For this subset of experiments, the cells were exposed to increasing concentrations of ABT- 888 for $24 \mathrm{~h}$ in order to detect early events occurring during the apoptotic process. As shown in Fig. 5D, only the full-length enzyme $(116 \mathrm{kDa})$ was detected in the lysates from the A375 or A375R cells treated with diluents or $5 \mu \mathrm{M}$ ABT- 888 for $24 \mathrm{~h}$. Apart from the full-length enzyme, in the lysates from both the A375 and A375R cells exposed to $25 \mu \mathrm{M}$ ABT-888, we observed the appearance of the $85-\mathrm{kDa}$ band corresponding to the $85-\mathrm{kDa}$ cleaved PARP fragment that increased in the cells exposed to $50 \mu \mathrm{M}$ ABT-888. Interestingly, a very faint 85-kDa band appeared in lysates from A375R but not A375 cells treated with $10 \mu \mathrm{M}$ ABT-888, suggesting that, unlike the sensitive cells, the resistant A375 cells were more responsive to ABT-888-induced, PARP1-mediated apoptosis (Fig. 5D). This finding is in agreement with the Annexin V assay data, showing that a more robust increase in apoptosis was elicited by ABT- 888 in the resistant cells as compared to the BRAFisensitive cell population (Fig. 5C). Taken together, these findings indicate that ABT- 888 reduces the viability and induces the apoptosis of both A375 and A375R melanoma cells in a dose-dependent manner. The findings also suggest that BRAFi-resistant melanoma cells are more responsive to the pro-apoptotic effects exerted by ABT-888 than their sensitive counterparts.

Effect of ABT-888 on cytoskeletal organization, migration and the Matrigel invasion of melanoma cells. Recently, it has been reported that PARP confers increased melanoma cell motility and that PARP inactivation represses actin cytoskeleton machinery, which is required for the acquisition of cell migratory ability $(40,41)$. Therefore, in this study, we 

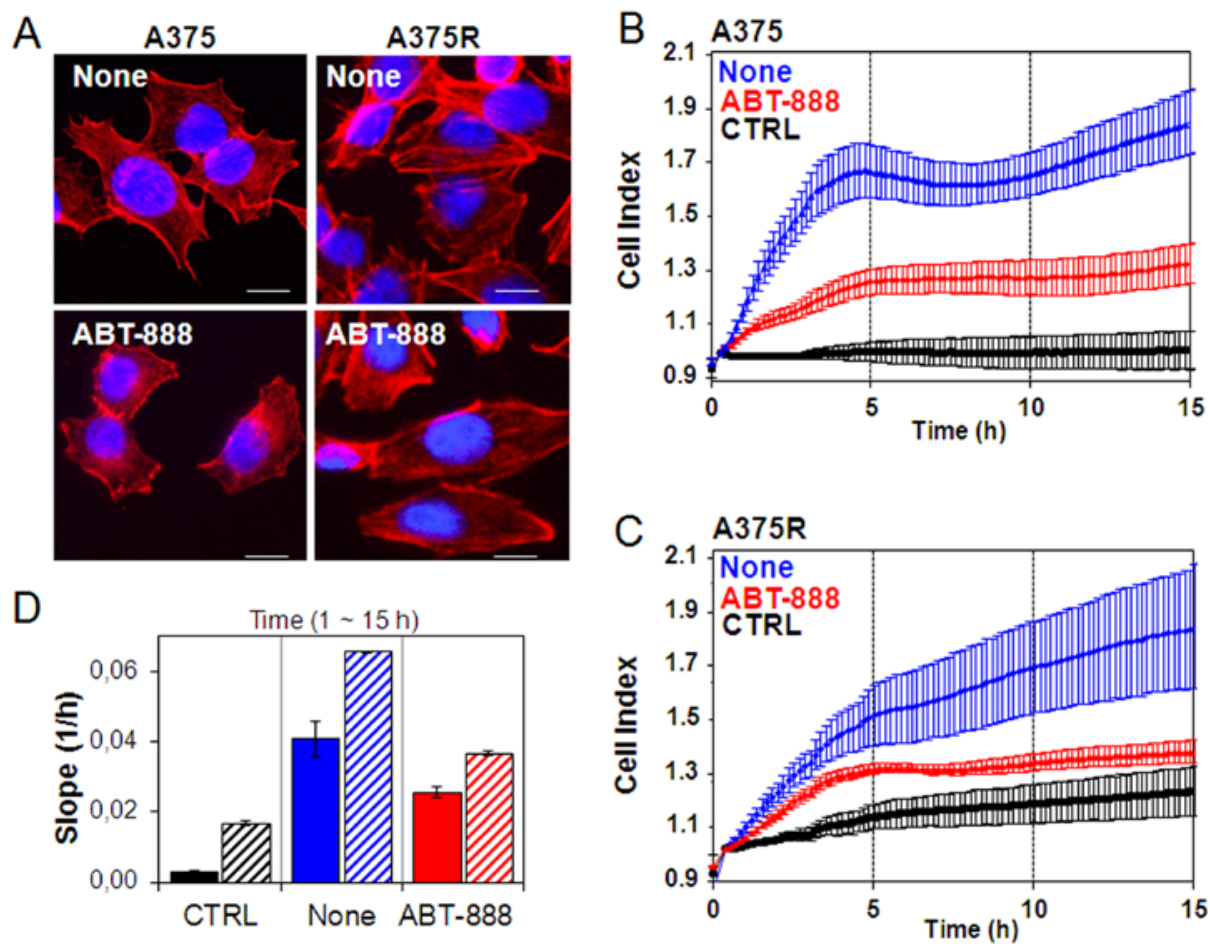

Figure 6. Inhibitory effect of ABT-888 on cytoskeletal organization and motility of melanoma cells. The A375 and A375R cells were treated with diluent or $5 \mu \mathrm{M}$ ABT- 888 for $24 \mathrm{~h}$ in complete growth medium at $37^{\circ} \mathrm{C}$ in humidified air with $5 \% \mathrm{CO}_{2}$ and then cytoskeletal organization and cell migration ability were analyzed. (A) Representative images of A375 and A375R treated with diluents (none) or $5 \mu \mathrm{M}$ ABT-888 and stained with rhodamine-conjugated phalloidin Nuclei were stained blue with DAPI. Scale bar, $10 \mu \mathrm{m}$; original magnification, x400. (B-D) Migration of (B) A375 and (C) A375R cells treated with diluents (none) or $5 \mu \mathrm{M}$ ABT- 888 for $24 \mathrm{~h}$ in complete growth medium, monitored in real-time for $15 \mathrm{~h}$ as changes in cell index by the xCELLigence system. Cells were seeded in CIM-16-well plates and allowed to migrate at $37^{\circ} \mathrm{C}, 5 \% \mathrm{CO}_{2}$, toward diluents (CTRL) or RPMI containing $10 \%$ FBS (none). Data represent the means \pm SD from a quadruplicate experiment. (D) Slopes represent the alteration rate in the cell index generated in a 1-15 h time frame by A375 (solid bars) or A375R (dashed bars) cells.

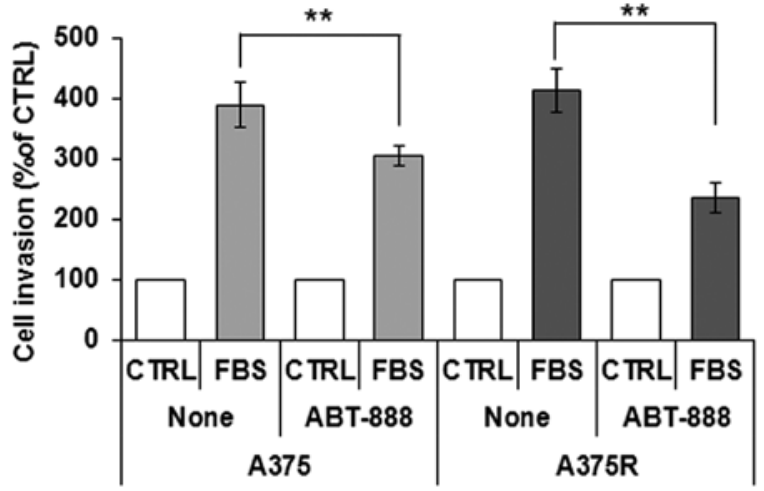

Figure 7. Inhibitory effect of ABT-888 on the invasion of melanoma cells on Matrigel. The A375 or A375R cells exposed to diluents (none) or $5 \mu \mathrm{M}$ ABT-888 for $24 \mathrm{~h}$ were re-suspended in serum-free medium and seeded on polymerized Matrigel in Boyden chambers. Cells were allowed to invade the Matrigel toward $10 \%$ FBS for $18 \mathrm{~h}$. For quantitative analysis of cell invasion, the value assessed in the absence of FBS (control; CTRL) was taken as $100 \%$ and all values were reported relative to that. Data represent the means \pm SD of 3 experiments performed in triplicate. ${ }^{* * *} \mathrm{P}<0.001$, statistically significant difference.

investigated whether ABT-888 treatment exerts an effect on cytoskeletal organization and the motility of sensitive and resistant A375 cells. In order to investigate the early intracellular effects on cytoskeletal rearrangements occurring during ABT- 888 treatment and to avoid any effect of ABT- 888 on cell viability and apoptosis, cytoskeletal organization and cell motility were analyzed in the A375 and A375R cells exposed for $24 \mathrm{~h}$ to diluent (none) or to a low concentration of ABT- 888 $(5 \mu \mathrm{M})$. As the rhodamine-phalloidin staining of F-actin polymerization revealed, the sensible A375 cells exhibited few stress fibers parallel to the longitudinal axis of the cells and actin aggregates near the membrane (Fig. 6A). Conversely, the acquisition of resistance to BRAFi induced marked changes in cell morphology. The A375R cells acquired a more elongated morphology which reflected a marked reorganization of actin into stress fibres spanning the length of the cells, often localized at one pole of the cell (Fig. 6A). ABT-888 markedly altered the cytoskeletal organization of both the A375 and A375R cells with a general reduction in the amount of stress fibres. In particular, treatment of the A375 cells with ABT-888 led to the appearance of condensed aggregates, mostly localized below the membrane (Fig. 6A). These effects were not due to ABT-888-induced apoptosis as no form of cleaved PARP was found in the cells exposed to $5 \mu \mathrm{M}$ ABT- 888 for $24 \mathrm{~h}$ (Fig. 5D).

Alterations in cytoskeletal organization reflect the capability of cells to migrate. In this study, the ability of the sensitive and dabrafenib-resistant A375 cells to migrate toward serum (employed as a source of chemoattractant), was assessed using the xCELLigence RTCA technology. The A375 and A375R cells treated with diluents or $5 \mu \mathrm{M}$ ABT- 888 for $24 \mathrm{~h}$ were seeded in the upper compartment of CIM plates. The lower chambers were filled with RPMI (CTRL) or RPMI containing $10 \%$ FBS (none). Cell migration was monitored in real-time for $15 \mathrm{~h}$ as the cell index changes due to the adhesion of migrating 
cells to microelectrodes (Fig. 6B-C). Of note, we found that BRAFi resistance was associated with increased basal cell migration, as compared to the sensitive A375 cells, probably due to the elongated morphology that reflected the high concentration of the stress fibers spanning the length of A375R cells. Accordingly, the A375R cells were able to respond more efficiently to the chemotactic gradient (approximately a 3-fold increase) than the A375 cells, as shown in the plot which recapitulates the cell index changes generated in the 1-15 $\mathrm{h}$ time frame (Fig. 6D). ABT-888 treatment did not affect basal cell migration, as compared to the untreated cells (data not shown). Despite different cell migratory abilities, both the A375 and A375R cells responded to ABT-888 treatment to a similar extent, as ABT-888 reduced the directional migration of the A375 and A375R cells by 37 and 45\%, respectively (Fig. 6B-D). Since cell motility is a prerequisite for the acquisition of an invasive phenotype, we examined the effects of ABT- 888 treatment on the capability of A375 and A375R cells to cross the Matrigel. The cells were seeded in the upper compartment of Boyden chambers. The lower chambers were filled with RPMI (CTRL) or RPMI containing $10 \%$ FBS (FBS). We found that the A375 and A375R cells were able to cross the Matrigel to a similar extent (391 and 414\% of the basal cell invasion, respectively). According to the cell migration data, pre-exposure of the cells to $5 \mu \mathrm{M}$ ABT-888 for $24 \mathrm{~h}$ caused a 22 and $44 \%$ inhibition of the A375 and A375R cell invasive ability, respectively (Fig. 7). Taken together, our data highlight the pivotal role of PARP1 in the migratory and invasive ability of melanoma cells, raising the possibility that ABT- 888 may be considered, not only as a pro-apoptotic drug for the treatment of BRAFi-resistant melanoma cells, but also as a good candidate for preventing the migration and invasion of melanoma cells.

\section{Discussion}

In recent years, the development of therapies targeting BRAF and MEK to block the MAPK pathway has improved the overall survival of patients with melanoma. Despite these landmark changes in practice, the majority of patients are either intrinsically resistant or rapidly acquire resistance to MAPK pathway inhibitors, imposing more complex combinatorial therapeutic strategies $(42,43)$. Thus, the aim of this study was to investigate the possibility that PARP1/2 inhibitors may be taken into account for the design of novel combinatorial therapies. PARP1 expression is associated with the recurrence and/or progression of the disease (44). Thus, the use of PARP inhibitors in combination with other cytotoxic agents may represent an efficacious strategy. Accumulating evidence indicates that PARP1 inhibitors abrogate resistance to temozolomide, increasing the survival of tumor-bearing mice with respect to treatment with temozolomide as a single agent, and in preclinical tumor models (including melanoma), as well as in clinical trials $(31,45-47)$.

Among the PARP inhibitors, ABT-888 (veliparib) appears most effective when used to treat solid tumors with underlying defects in DNA repair, or when combined with DNA-damaging agents and is currently undergoing clinical trials $(48,49)$. In this study, we present evidence that, in vitro, ABT- 888 reduces the viability and induces the apoptosis of melanoma cell lines, independently of their BRAF/NRAS mutation status and in a dose-dependent manner, with the maximal effect being reached in the 25-50 $\mu \mathrm{M}$ concentration range. We found that ABT-888 promoted the apoptosis of both dabrafenib-sensitive and -resistant A375 cells. Although we did not explore the efficacy of ABT-888 alone in preventing melanoma growth in mouse models, or its pharmacokinetic proprieties, our findings strongly support the hypothesis that ABT- 888 may prove to be useful in the treatment of BRAFi-resistant melanoma cells, in combination with other cytotoxic agents.

In addition to its direct role in DNA damage recognition and repair, emerging evidence indicates that PARP1 regulates the expression of key factors, such as vimentin and VE-cadherin and is involved in epithelial-mesenchymal transition (41). Furthermore, PARP inactivation has been documented to suppress actin cytoskeleton machinery, which is required for the acquisition of the cell migratory ability $(40,50,51)$. Consequently, targeting and inhibiting these important biological functions may open up another avenue for melanoma therapy. In this study, we provide evidence that ABT- 888 prevents the directional migration of dabrafenib-sensitive, as well as dabrafenib-resistant A375 cells exposed to $5 \mu \mathrm{M}$ ABT-888 for $24 \mathrm{~h}$, arguing that combinatorial approaches, including ABT-888, effectively improve the prognosis of patients with metastatic melanoma. Notably, the ABT-888 inhibitory effect on cell migration cannot be due to apoptosis, since at the $5 \mu \mathrm{M}$ concentration, ABT-888 failed to elicit PARP fragmentation in both the dabrafenib-sensitive and -resistant A375 cells (Fig. 5D). Of note, we also found that the melanoma cells failed to cross the Matrigel in Boyden chamber assays following treatment with $5 \mu \mathrm{M}$ ABT-888 for $24 \mathrm{~h}$. Zhu et al reported that the PARP1 inhibitor, benzyl-isothiocyanate, prevented the invasion of hepatocellular carcinoma cells by downregulating the expression of matrix metalloproteinase (MMP)2 and MMP9 (52). In this study, although we did not investigate the molecular mechanisms underlying the inhibition of melanoma invasiveness by ABT-888, or whether, similar to benzyl-isothiocyanate, ABT-888 decreases protease activity, our findings encourage the inclusion of ABT-888 in combinatorial therapies for the management of patients with metastatic disease. Considering that, similar to other PARP1 inhibitors (53), ABT-888 has been proven to cross the blood brain barrier (31), our findings support the notion that ABT-888 may provide some advantages for patients with melanoma with brain metastases.

In conclusion, our data highlight the pivotal role of PARP1 in the migratory and invasive ability of melanoma cells, raising the possibility that ABT-888 may be considered, not only as a pro-apoptotic drug for the treatment of BRAFi-resistant melanoma cells, but also a good candidate for preventing the migration and invasion of melanoma cells, arguing that combinatorial approaches including ABT-888 may effectively improve the prognosis of patients with metastatic melanoma.

\section{Acknowledgements}

The authors would like to thank Dr F.M. Marincola (Sidra Medical and Research Center, Doha, Qatar) and Dr A. Ribas (UCLA Medical Center, Santa Monica, CA , USA) for kindly providing the human melanoma cells. The authors would also like to thank AbbVie Inc. (Chicago, IL, USA) for providing the ABT-888. 


\section{Funding}

PAA received research funds from Melanoma Onlus Foundation. MLM received research funds from the University of Naples 'Parthenope' - (DSMB 187, CUP I6I15000090005).

\section{Availability of data and materials}

All data generated or analyzed during this study are included in this published article.

\section{Authors' contributions}

PAA and MLM conceptualized and designed this study. MLM, MVC and GPa contributed to the analysis and interpretation of the data and wrote the manuscript. FF, CR, MM, RC, GG and GPi performed the experiments. All authors contributed to revise the manuscript and approved the final manuscript.

\section{Ethics approval and consent to participate}

Not applicable.

\section{Patient consent for publication}

Not applicable.

\section{Competing interests}

PAA has a consultant / advisory role for BMS, Roche-Genentech, MSD, Novartis, Amgen, Array, Merck-Serono. PAA received research funds from Bristol-Myers Squibb, Roche-Genentech, Array. The other authors declare that they have no competing interests.

\section{References}

1. Tsao H, Chin L, Garraway LA and Fisher DE: Melanoma: From mutations to medicine. Genes Dev 26: 1131-1155, 2012.

2. Akbani R, Akdemir KC, Aksoy BA, Albert M, Ally A, Amin SB, Arachchi H, Arora A, Auman JT, Ayala B, et al: Cancer Genome Atlas Network: Genomic classification of cutaneous melanoma. Cell 161: 1681-1696, 2015.

3. Davies H, Bignell GR, Cox C, Stephens P, Edkins S, Clegg S, Teague J, Woffendin H, Garnett MJ, Bottomley W, et al: Mutations of the BRAF gene in human cancer. Nature 417: 949-954, 2002.

4. Dhomen N and Marais R: BRAF signaling and targeted therapies in melanoma. Hematol Oncol Clin North Am 23: 529-545, 2009

5. Fecher LA, Amaravadi RK and Flaherty KT: The MAPK pathway in melanoma. Curr Opin Oncol 20: 183-189, 2008.

6. Garnett MJ and Marais R: Guilty as charged: B-RAF is a human oncogene. Cancer Cell 6: 313-319, 2004.

7. Chapman PB, Hauschild A, Robert C, Haanen JB, Ascierto P, Larkin J, Dummer R, Garbe C, Testori A, Maio M, et al; BRIM-3 Study Group: Improved survival with vemurafenib in melanoma with BRAF V600E mutation. N Engl J Med 364: 2507-2516, 2011.

8. Flaherty KT, Puzanov I, Kim KB, Ribas A, McArthur GA, Sosman JA, O'Dwyer PJ, Lee RJ, Grippo JF, Nolop K, et al: Inhibition of mutated, activated BRAF in metastatic melanoma. N Engl J Med 363: 809-819, 2010.

9. Eggermont AM, Spatz A and Robert C: Cutaneous melanoma. Lancet 383: 816-827, 2014.

10. Palmieri G, Ombra M, Colombino M, Casula M, Sini M, Manca A, Paliogiannis P, Ascierto PA and Cossu A: Multiple molecular pathways in melanomagenesis: Characterization of therapeutic targets. Front Oncol 5: 183, 2015.
11. Johannessen CM, Boehm JS, Kim SY, Thomas SR, Wardwell L, Johnson LA, Emery CM, Stransky N, Cogdill AP, Barretina J, et al: COT drives resistance to RAF inhibition through MAP kinase pathway reactivation. Nature 468: 968-972, 2010.

12. Nazarian R, Shi H, Wang Q, Kong X, Koya RC, Lee H, Chen Z, Lee MK, Attar N, Sazegar H, et al: Melanomas acquire resistance to B-RAF(V600E) inhibition by RTK or N-RAS upregulation. Nature 468: 973-977, 2010.

13. Poulikakos PI, Persaud Y, Janakiraman M, Kong X, Ng C, Moriceau G, Shi H, Atefi M, Titz B, Gabay MT, et al: RAF inhibitor resistance is mediated by dimerization of aberrantly spliced BRAF(V600E). Nature 480: 387-390, 2011.

14. Whittaker SR, Theurillat JP, Van Allen E, Wagle N, Hsiao J, Cowley GS, Schadendorf D, Root DE and Garraway LA: A genome-scale RNA interference screen implicates NF1 loss in resistance to RAF inhibition. Cancer Discov 3: 350-362, 2013.

15. Villanueva J, Infante JR, Krepler C, Reyes-Uribe P, Samanta M, Chen HY, Li B, Swoboda RK, Wilson M, Vultur A, et al: Concurrent MEK2 mutation and BRAF amplification confer resistance to BRAF and MEK inhibitors in melanoma. Cell Reports 4: 1090-1099, 2013.

16. Wagle N, Van Allen EM, Treacy DJ, Frederick DT, Cooper ZA, Taylor-Weiner A, Rosenberg M, Goetz EM, Sullivan RJ, Farlow DN, et al: MAP kinase pathway alterations in BRAF-mutant melanoma patients with acquired resistance to combined RAF/MEK inhibition. Cancer Discov 4: 61-68, 2014.

17. Shi H, Hugo W, Kong X, Hong A, Koya RC, Moriceau G, Chodon T, Guo R, Johnson DB, Dahlman KB, et al: Acquired resistance and clonal evolution in melanoma during $\mathrm{BRAF}$ inhibitor therapy. Cancer Discov 4: 80-93, 2014.

18. Ascierto PA, Schadendorf D, Berking C, Agarwala SS van Herpen CM, Queirolo P, Blank CU, Hauschild A, Beck JT, St-Pierre A, et al: MEK162 for patients with advanced melanoma harbouring NRAS or Val600 BRAF mutations: A non-randomised, open-label phase 2 study. Lancet Oncol 14: 249-256, 2013.

19. Kim DW and Patel SP: Profile of selumetinib and its potential in the treatment of melanoma. Onco Targets Ther 7: 1631-1639, 2014.

20. King JW and Nathan PD: Role of the MEK inhibitor trametinib in the treatment of metastatic melanoma. Future Oncol 10: 1559-1570, 2014

21. Long GV, Weber JS, Infante JR, Kim KB, Daud A, Gonzalez R, Sosman JA, Hamid O, Schuchter L, Cebon J, et al: Overall survival and durable responses in patients with BRAF V600-mutant metastatic melanoma receiving dabrafenib combined with trametinib. J Clin Oncol 34: 871-878, 2016.

22. Ascierto PA, McArthur GA, Dréno B, Atkinson V, Liszkay G, Di Giacomo AM, Mandalà M, Demidov L, Stroyakovskiy D, Thomas L, et al: Cobimetinib combined with vemurafenib in advanced BRAF(V600)-mutant melanoma (coBRIM): Updated efficacy results from a randomised, double-blind, phase 3 trial. Lancet Oncol 17: 1248-1260, 2016.

23. Van Allen EM, Wagle N, Sucker A, Treacy DJ, Johannessen CM, Goetz EM, Place CS, Taylor-Weiner A, Whittaker S, Kryukov GV, et al; Dermatologic Cooperative Oncology Group of Germany (DeCOG): The genetic landscape of clinical resistance to RAF inhibition in metastatic melanoma. Cancer Discov 4: 94-109, 2014.

24. Welsh SJ, Rizos H, Scolyer RA and Long GV: Resistance to combination BRAF and MEK inhibition in metastatic melanoma: Where to next? Eur J Cancer 62: 76-85, 2016.

25. Hassa PO and Hottiger MO: The diverse biological roles of mammalian PARPS, a small but powerful family of poly-ADPribose polymerases. Front Biosci 13: 3046-3082, 2008.

26. Rouleau M, Patel A, Hendzel MJ, Kaufmann SH and Poirier GG: PARP inhibition: PARP1 and beyond. Nat Rev Cancer 10: 293-301, 2010.

27. Schreiber V, Amé JC, Dollé P, Schultz I, Rinaldi B, Fraulob V, Ménissier-de Murcia J and de Murcia G: Poly(ADP-ribose) polymerase-2 (PARP-2) is required for efficient base excision DNA repair in association with PARP-1 and XRCC1. J Biol Chem 277: 23028-23036, 2002.

28. Memisoglu A and Samson L: Base excision repair in yeast and mammals. Mutat Res 451: 39-51, 2000.

29. Schiewer MJ and Knudsen KE: Transcriptional roles of PARP1 in cancer. Mol Cancer Res 12: 1069-1080, 2014.

30. Tentori L, Muzi A, Dorio AS, Bultrini S, Mazzon E, Lacal PM, Shah GM, Zhang J, Navarra P, Nocentini G, et al: Stable depletion of poly (ADP-ribose) polymerase-1 reduces in vivo melanoma growth and increases chemosensitivity. Eur J Cancer 44: 1302-1314, 2008. 
31. Donawho CK, Luo Y, Luo Y, Penning TD, Bauch JL, Bouska JJ, Bontcheva-Diaz VD, Cox BF, DeWeese TL, Dillehay LE, et al: ABT-888, an orally active poly(ADP-ribose) polymerase inhibitor that potentiates DNA-damaging agents in preclinical tumor models. Clin Cancer Res 13: 2728-2737, 2007.

32. Nishikawa T, Matsumoto K, Tamura K, Yoshida H, Imai Y, Miyasaka A, Onoe T, Yamaguchi S, Shimizu C, Yonemori K, et al: Phase 1 dose-escalation study of single-agent veliparib in Japanese patients with advanced solid tumors. Cancer Sci 108: 1834-1842, 2017.

33. Middleton MR, Friedlander P, Hamid O, Daud A, Plummer R, Falotico N, Chyla B, Jiang F, McKeegan E, Mostafa NM, et al Randomized phase II study evaluating veliparib (ABT-888) with temozolomide in patients with metastatic melanoma. Ann Oncol 26: 2173-2179, 2015.

34. Palma JP, Wang YC, Rodriguez LE, Montgomery D, Ellis PA, Bukofzer G, Niquette A, Liu X, Shi Y, Lasko L, et al: ABT-888 confers broad in vivo activity in combination with temozolomide in diverse tumors. Clin Cancer Res 15: 7277-7290, 2009.

35. Carta F, Demuro PP, Zanini C, Santona A, Castiglia D, D'Atri S, Ascierto PA, Napolitano M, Cossu A, Tadolini B, et al: Analysis of candidate genes through a proteomics-based approach in primary cell lines from malignant melanomas and their metastases. Melanoma Res 15: 235-244, 2005.

36. Chang CC, Pirozzi G, Wen SH, Chung IH, Chiu BL, Errico S, Luongo M, Lombardi ML and Ferrone S: Multiple structural and epigenetic defects in the human leukocyte antigen class I antigen presentation pathway in a recurrent metastatic melanoma following immunotherapy. J Biol Chem 290: 26562-26575, 2015

37. Carriero MV, Bifulco K, Ingangi V, Costantini S, Botti G, Ragone C, Minopoli M, Motti ML, Rea D, Scognamiglio G, et al: Retro-inverso urokinase receptor antagonists for the treatment of metastatic sarcomas. Sci Rep 7: 1312, 2017.

38. Ragone $\mathrm{C}$, Minopoli M, Ingangi V, Botti G, Fratangelo $\mathrm{F}$ Pessi A, Stoppelli MP, Ascierto PA, Ciliberto G, Motti ML, et al: Targeting the cross-talk between Urokinase receptor and Formyl peptide receptor type 1 to prevent invasion and trans-endothelial migration of melanoma cells. J Exp Clin Cancer Res 36: 180, 2017.

39. Ascierto PA, Kirkwood JM, Grob JJ, Simeone E, Grimaldi AM, Maio M, Palmieri G, Testori A, Marincola FM and Mozzillo N: The role of BRAF V600 mutation in melanoma. J Transl Med 10: $85,2012$.

40. Rom S, Zuluaga-Ramirez V, Reichenbach NL, Dykstra H, Gajghate S,PacherPand Persidsky Y:PARPinhibition inleukocytes diminishes inflammation via effects on integrins/cytoskeleton and protects the blood-brain barrier. J Neuroinflammation 13: 254, 2016.

41. Rodríguez MI, Peralta-Leal A, O'Valle F, Rodriguez-Vargas JM, Gonzalez-Flores A, Majuelos-Melguizo J, López L, Serrano S de Herreros AG, Rodríguez-Manzaneque JC, et al: PARP-1 regulates metastatic melanoma through modulation of vimentininduced malignant transformation. PLoS Genet 9: e1003531, 2013
42. Ascierto PA, Atkins M, Bifulco C, Botti G, Cochran A, Davies M, Demaria S, Dummer R, Ferrone S, Formenti S, et al: Future perspectives in melanoma research: meeting report from the 'Melanoma Bridge': Napoli, December 3rd-6th 2014. J Transl Med 13: 374, 2015.

43. Leonardi GC, Falzone L, Salemi R, Zanghì A, Spandidos DA, Mccubrey JA, Candido S and Libra M: Cutaneous melanoma: From pathogenesis to therapy (Review). Int J Oncol 52: 1071-1080, 2018.

44. Staibano S, Pepe S, Lo Muzio L, Somma P, Mascolo M, Argenziano G, Scalvenzi M, Salvatore G, Fabbrocini G, Molea G, et al: Poly(adenosine diphosphate-ribose) polymerase 1 expression in malignant melanomas from photoexposed areas of the head and neck region. Hum Pathol 36: 724-731, 2005.

45. Tentori L, Leonetti C, Scarsella M, D'Amati G, Vergati M, Portarena I, Xu W, Kalish V, Zupi G, Zhang J, et al: Systemic administration of GPI 15427, a novel poly(ADP-ribose) polymerase-1 inhibitor, increases the antitumor activity of temozolomide against intracranial melanoma, glioma, lymphoma. Clin Cancer Res 9: 5370-5379, 2003.

46. Lok BH, Gardner EE, Schneeberger VE, Ni A, Desmeules P, Rekhtman N, de Stanchina E, Teicher BA, Riaz N, Powell SN, et al: PARP inhibitor activity correlates with SLFN11 expression and demonstrates synergy with temozolomide in small cell lung cancer. Clin Cancer Res 23: 523-535, 2017.

47. Ohmoto A and Yachida S: Current status of poly(ADP-ribose) polymerase inhibitors and future directions. OncoTargets Ther 10: 5195-5208, 2017

48. Wagner LM: Profile of veliparib and its potential in the treatment of solid tumors. OncoTargets Ther 8: 1931-1939, 2015.

49. Sonnenblick A, de Azambuja E, Azim HA Jr and Piccart M: An update on PARP inhibitors - moving to the adjuvant setting. Nat Rev Clin Oncol 12: 27-41, 2015.

50. Barboro P, Ferrari N, Capaia M, Petretto A, Salvi S, Boccardo S and Balbi C: Expression of nuclear matrix proteins binding matrix attachment regions in prostate cancer. PARP-1: New player in tumor progression. Int J Cancer 137: 1574-1586, 2015.

51. Inbar D, Cohen-Armon M and Neumann D: Erythropoietin-driven signalling and cell migration mediated by polyADP-ribosylation. Br J Cancer 107: 1317-1326, 2012.

52. Zhu M, Li W, Dong X, Chen Y, Lu Y, Lin B, Guo J and Li M: Benzyl-isothiocyanate induces apoptosis and inhibits migration and invasion of hepatocellular carcinoma cells in vitro. J Cancer 8: 240-248, 2017.

53. Tentori L, Leonetti C, Scarsella M, Vergati M, Xu W, Calvin D, Morgan L, Tang Z, Woznizk K, Alemu C, et al: Brain distribution and efficacy as chemosensitizer of an oral formulation of PARP-1 inhibitor GPI 15427 in experimental models of CNS tumors. Int J Oncol 26: 415-422, 2005 .

This work is licensed under a Creative Commons Attribution-NonCommercial-NoDerivatives 4.0 International (CC BY-NC-ND 4.0) License. 